\title{
At the intersections of populism, nationalism and Islam: justice and development party and populist reconfiguration of religion in politics
}

\section{Q1 Bilge Yabanci}

Marie Curie Fellow, Dipartimento Di Filosofi a e Beni Culturali Dorsoduro 3284/D, University Ca' Foscari of Venice, Venezia, Italy

\begin{abstract}
This study examines the relationship between populism, nationalism and religion through evidence from Turkey's Justice and Development Party (AKP) rule. The literature on the populism's rapport with nationalism has developed in isolation from the burgeoning theorization of populism-religion nexus. This study has a two-fold contribution. Theoretically, it advances a historical approach to deepen our understanding of the widespread appeal of contemporary populism. It argues that populism can capitalize on unique contextual fusions of religion and ethnic (secular) nationalism that originate from historical legacies and ideas of modern nation-building to (re)construct the antagonistic discourse dividing the society into two camps of 'the people' and 'the elites'. Empirically, by drawing upon discourse theory and empirical analysis of the AKP's public discourse, the study offers a nuanced approach to the AKP's much-debated stance on religion as an ideology versus instrument. Three areas are investigated to exemplify AKP's construction of populist dichotomy: a) ethnic and religious minorities, b) women, and c) youth. The analysis reveals that the AKP has built three different, and at times, contradictory articulations of "the people as underdogs', 'people as nation' and 'people as the ummah' against 'the secular elites', 'the enemies within' and 'the West', respectively.
\end{abstract}

\section{Introduction}

The resurgence of populist movements and leaders across the world has created a vast literature on populism focused on several definitions and populism's effect on democracy based on case-oriented in-depth and medium- $\mathrm{N}$ comparative studies. ${ }^{1}$ Populism's

CONTACT Bilge Yabanci bilge.yabanci@unive.it Marie Curie Fellow, Dipartimento Di Filosofi a e Beni Culturali Dorsoduro 3284/D, L' Università Ca' Foscari Venezia, Venezia 30123, Italy

'Jan-Werner Muller, What Is Populism? (University of Pennsylvania Press, 2016); Benjamin Moffitt and Simon Tormey,

'Rethinking Populism: Politics, Mediatisation and Political Style,' Political Studies 62, no. 2 (2013): 381-97, https://doi. org/10.1111/1467-9248.12032; Cas Mudde, Populist Radical Right Parties in Europe (Cambridge: Cambridge University Press, 2007); Ernesto Laclau, 'Populism: What's in a Name?,' in Populism and the Mirror of Democracy, Francisco Panizza (London: Verso, 2005), 32-49; Carlos de la Torre, 'In the Name of the People: Democratization, Popular Organizations, and Populism in Venezuela, Bolivia, and Ecuador,' Revista Europea de Estudios Latinoamericanos y Del Caribe / European Review of Latin American and Caribbean Studies, no. 95 (2013): 27-48; Paul D. Kenny, Populism and Patronage: Why Populists Win Elections in India, Asia, and Beyond (Oxford University Press, 2017).

(c) 2021 British Society for Middle Eastern Studies 
relations with other ideologies have attracted lesser attention, even though there is a widely accepted argument that populism has a 'thin' core and needs to borrow and capitalize on other belief systems and ideologies to develop political positions on salient issues. $^{2}$ Among them, religion and nationalism have an increasingly key footing in shaping populist claims. Populist movements and leaders across the world often capitalize on religious messages and symbols on the one hand, and nationalism, on the other.

However, populism's relations with nationalism and religion remain under-studied for two reasons. First, the literature predominantly focuses on European and North American contexts to explain how radical right populists utilize 'Christian values' or nationalism to draw cultural and social boundaries between 'the native people' and (Muslim) immigrants. ${ }^{3}$ As a result, the findings from which the current theorization of populism's rapport with nationalism or religion is drawn mostly originate from European and North American radical right-wing populism. Second, the relationship of populism with nationalism and religion has developed in parallel but without a dialogue from each other. Extant studies have disregarded the role of historical co-development and mutual influence of religion and nationalism in facilitating the contemporary populist constructions of 'the people' versus 'the elites' antagonism.

This study aims to shed light on how populists rely on the historical legacies and ideas that underpinned the modern nation-building to (re)construct their antagonistic discourse dividing the society into two irreconcilable camps. This endeavour is important because besides the face value of religious and/or nationalist cues in the populist discourse, the role of religion in constructing secular national identities and their popular legitimation in the modern nation-state provide a historical, cultural and political background for populists to exalt the people and popular will. ${ }^{4}$ Moreover, an artificial separation of religion and nationalism in the study of populism does not correspond to reality. Religion, in many contexts, has proved to be not a competitor but a close companion of (secular) nationalism. ${ }^{5}$ By relying on the historical legacies of building the modern nationstate, populists would find it easier to 'resonate' with the wider society when validating their claim about an incessant antagonism between the people and the elites/enemies. ${ }^{6}$ Resonance is crucial for social and political movements' successful appeal to the masses. Cognitive sociology and social movement scholarships have demonstrated that messages that draw upon cultural and historical sets of stories, symbols, images, arguments can

\footnotetext{
${ }^{2}$ Cas Mudde and Cristóbal Rovira Kaltwasser, Populism: A Very Short Introduction, Very Short Introductions (Oxford, New York: Oxford University Press, 2017).

${ }^{3}$ Nadia Marzouki, Duncan McDonnell, and Olivier Roy, eds., Saving the People: How Populists Hijack Religion (London: C Hurst \& Co Publishers Ltd, 2016); Benjamin De Cleen and Yannis Stavrakakis, 'Distinctions and Articulations: A Discourse Theoretical Framework for the Study of Populism and Nationalism,' Javnost-The Public 24, no. 4 (2 October 2017): 301-19, https://doi.org/10.1080/13183222.2017.1330083; Rogers Brubaker, 'Between Nationalism and Civilizationism: The European Populist Moment in Comparative Perspective,' Ethnic and Racial Studies 40, no. 8 (21 June 2017): 1191-1226, https://doi.org/10.1080/01419870.2017.1294700.

${ }^{4}$ Philip S. Gorski, 'The Mosaic Moment: An Early Modernist Critique of Modernist Theories of Nationalism,' American Journal of Sociology 105, no. 5 (2000): 1428-68.

${ }^{5}$ Barbara-Ann J. Rieffer, 'Religion and Nationalism: Understanding the Consequences of a Complex Relationship,' Ethnicities 3, no. 2 (1 June 2003): 215-42, https://doi.org/10.1177/1468796803003002003; Roger Friedland, 'Religious Nationalism and the Problem of Collective Representation,' Annual Review of Sociology 27, no. 1 (2001): 125-52, https:// doi.org/10.1146/annurev.soc.27.1.125; Peter van der Veer, Religious Nationalism: Hindus and Muslims in India (University of California Press, 1994).

${ }^{6}$ On resonance, see: David Snow and Robert Benford, 'Ideology, Frame Resonance, and Participant Mobilization,' in From Structure to Action: Comparing Social Movement Research across Cultures, ed. Bert Klandermans, Hanspeter Kriesi, and Sidney G. Tarrow, vol. International social movement research (Greenwich, Conn: JAI Press, 1988), 197-217.
} 
'inspire and legitimate activities and campaigns'. ${ }^{7}$ By using historically interwoven frames of nation and religion, populists can render certain facts and events visible for a given society and align its messages with the belief system of groups they wish to mobilize.

This study investigates how a populist authoritarian government capitalizes on the historically cultivated concord between a dominant religion and ethnic nationalism through the case of Turkey and the Justice and Development Party (AKP). It demonstrates how the AKP exploits various historical and intellectual traditions and ideologies that promoted a specific fusion between nationalism and Islam to construct the very core of populist politics, namely the incessant struggle between 'the unified and virtuous people' and 'the elites'. The AKP has arguably fashioned one of the most enigmatic cases concerning the relationship between populism, religion and nationalism. It is a splinter party from the National Outlook Movement, a unique Islamist movement that goes back to the 1970s. When the AKP was founded in the early 2000s, it was mostly considered as a novel synthesis of democratic secular politics and religious appeal that had long been considered incompatible and zero-sum in Turkey. ${ }^{8}$ However, after the AKP consolidated its power through consecutive electoral victories in 2007 and 2011, and monopolized democratic institutions and initiated a slow autocratization, the party increasingly utilized religious references and policies. ${ }^{9}$

To date, two arguments emerged in the literature to explain the role that religion plays in the authoritarian turn. On the one hand, some argue that religion (particularly Islamism) serves as a core ideology for the AKP. ${ }^{10}$ Ideologies are 'social cognitions that reflect the basic aims, interests and values of groups' and organize attitudes of groups and their members. ${ }^{11}$ As an ideology, Islamism provides a moral worldview, a guide that informs policy choices, public statements and rulers' interpretation of the events. ${ }^{12}$ These scholars emphasize that the AKP's earlier democratic stance was merely a tactical move to oust the secular establishment by rallying a broad coalition of supporters. According to this view, the authoritarian

\footnotetext{
${ }^{7}$ Erving Goffman, Frame Analysis: An Essay on the Organization of Experience (Harvard University Press, 1974); Robert Benford and David Snow, 'Framing Processes and Social Movements: An Overview and Assessment,' Annual Review of Sociology 26 (2000): 611-39.

${ }^{8}$ Ümit Cizre, Secular and Islamic Politics in Turkey: The Making of the Justice and Development Party (Routledge, 2008); Ergun Özbudun, 'From Political Islam to Conservative Democracy: The Case of the Justice and Development Party in Turkey,' South European Society and Politics 11, no. 3-4 (1 December 2006): 543-57, https://doi.org/10.1080/ 13608740600856561; Ahmet Insel, 'The AKP and Normalizing Democracy in Turkey,' South Atlantic Quarterly 102, no. 2-3 (20 March 2003): 293-308, https://doi.org/10.1215/00382876-102-2-3-293; William Hale and Ergun Özbudun, Islamism, Democracy and Liberalism in Turkey: The Case of the AKP, Reprint edition (London: Routledge, 2011); Cihan Tugal, Passive Revolution: Absorbing the Islamic Challenge to Capitalism (Stanford, California: Stanford University Press, 2009), http://www.amazon.com/Passive-Revolution-Absorbing-Challenge-Capitalism/dp/0804761450.

${ }^{9}$ Autocratization is defined as a process of deterioration of prior institutions or practices associated with functioning democracy à la Dahl, such as democratic participation, competitiveness and accountability by elected incumbents. Autocratization leads to the formation of a hybrid regime where democratic institutions co-exist with authoritarian practices. Bermeo, Nancy. 'On Democratic Backsliding.' Journal of Democracy 27, no. 1 (2016): 5-19. https://doi.org/10. 1353/jod.2016.0012.

Q5 ${ }^{10}$ Ayhan Kaya, 'Islamisation of Turkey under the AKP Rule: Empowering Family, Faith and Charity,' South European Society and Politics 20, no. 1 (2 January 2015): 47-69, https://doi.org/10.1080/13608746.2014.979031; Birol Yesilada and Barry Rubin, eds., Islamization of Turkey under the AKP Rule, 1 edition (London: Routledge, 2010).

${ }^{11}$ Teun A. van Dijk, 'Principles of Critical Discourse Analysis,' Discourse \& Society 4, no. 2 (1993): 258, https://doi.org/10. $1177 / 0957926593004002006$.

${ }^{12}$ Nannerl O. Keohane, 'Philosophy, Theory, Ideology: An Attempt at Clarification,' Political Theory 4, no. 1 (1 February 1976): 80-100, https://doi.org/10.1177/009059177600400107.
} 
transformation of the AKP in the post-2013 period is not a turn to Islamism but a continuity for the AKP. After conquering the secular state, the AKP does no longer hide its Islamist ideology. ${ }^{13}$

On the other hand, some scholars contend that the AKP's religious discourse and policies demonstrate not an ideological conviction but instrumentalist power calculations of an authoritarian party to rally conservative and religious masses. ${ }^{14}$ In other words, religious tropes and language are adopted to entice pious and conservative audiences to ensure electoral victory. For instance, Yavuz argues that ${ }^{15}$ the AKP's sees Islam as 'a source of political mobilization'. Similarly, Öztürk ${ }^{16}$ argues that the AKP utilizes various religious groups' fear of survival to ensure the regime's stability. While both arguments have convincing grounds, this study offers new insights into the debate by bringing into the picture Turkey's unique historical intellectual traditions and ideologies that fused religion and nationalism. It is argued that they provide readily available templates that can be tailored and exploited for continuous mobilization for the AKP's populist authoritarian rule.

Therefore, this study offers a two-fold contribution. First, it offers a more nuanced analysis of the role of ethnic nationalism and religion in contemporary populist (authoritarian) politics. Against the dominant tendency in the populism literature that focuses on the contemporary politics and discourse of populists, the study aims to bring in a historical perspective to deepen our understanding of the widespread appeal of the current populist discourse. The theoretical aim is to identify how the historical processes that entangled religious identity and nationalism shape current populist discourse 'crafting' the people versus 'the elites and enemies'. The empirical analysis offers a perspective into how populist discourse can mystify and legitimize discriminatory practices, polarization, inequality and unjust social and political relations. Second, concerning modern Turkey studies, the study offers a nuanced approach to the AKP's much-debated stance on religion. The debate on religion as ideology versus instrument is irresolvable without discussing how the AKP created a new populism and religion-nationalism nexus. Historically, the nationalist-conservative (milliyetçi muhafazakar) tradition and TurkishIslam synthesis, irrevocably linked the ideological and the instrumental significance of religion. However, until the AKP, the nationalist-conservative position was 'a pettybourgeois and intellectual tradition' and imposed from top-down. ${ }^{17}$ The AKP has truly mainstreamed what was an intellectual and 'elite' tradition by giving it a people-centric and Manichaean, essence and built a political hegemony on its grounds.

\footnotetext{
${ }^{13}$ Ihsan Yilmaz, Greg Barton, and James Barry, 'The Decline and Resurgence of Turkish Islamism,' Journal of Citizenship and Globalization Studies 1, no. 1 (2017): 48-62, https://doi.org/10.1515/jcgs-2017-0005.

${ }^{14}$ Menderes Çınar, 'Turkey's "Western" or "Muslim" Identity and the AKP's Civilizational Discourse,' Turkish Studies 19, no. 2 (15 March 2018): 176-97, https://doi.org/10.1080/14683849.2017.1411199; Ihsan Yilmaz and Galib Bashirov, 'The AKP after 15 Years: Emergence of Erdoganism in Turkey,' Third World Quarterly 39, no. 9 (2 September 2018): 1812-30, https://doi.org/10.1080/01436597.2018.1447371.

${ }^{15} \mathrm{M}$. Hakan Yavuz, 'Understanding Turkish Secularism in the 21th Century: A Contextual Roadmap,' Southeast European and Black Sea Studies 19, no. 1 (2 January 2019): 55-78, https://doi.org/10.1080/14683857.2019.1576367.

${ }^{16} \mathrm{~A}$. Erdi Öztürk, 'An Alternative Reading of Religion and Authoritarianism: The New Logic between Religion and State in the AKP's New Turkey,' JSEEBS 19, no. 1 (2019): 79-98.

${ }^{17}$ Yuksel Taskin, 'Türk Sağı ve Aydınlar: Bir Aşk ve Nefret İlişkisini Anlamak,' in Türk Sağı: Mitler, Fetişler, Düşman Imgeleri, ed. Inci Özkan Kerestecioğlu and Güven Gürkan Öztan (Istanbul: Iletisim, 2012), 407-21.
} 
The first part takes a critical look at the debates in the populism literature about the role of religion and nationalism, and positions the study within these debates, lays out the research design and provides crucial background discussion on the right-wing political culture in Turkey dating back to the 19th-century Ottomanism and proto-Islamism. The empirical part analyses how the AKP has built on the historical fusion of religion and populism. Three areas have been chosen to investigate the AKP's populist discourse: a) ethnic and religious minorities, b) women, and c) youth. Ethnic and religious minorities can constitute both the allies against the elites and internal others for populists in constructing the people. Women and youth usually have strong symbolic and political connotations for populism because they are often perceived as the representatives of the ideal or respectable nation, family and gender relations. ${ }^{18}$ Discourse analysis investigates how the AKP constructs various and contradictory borders of 'the people' based on protoIslamism, pan-Ottomanism, and ethnodoxy, i.e. a belief system penetrated the social and political culture that there is 'a binding and mutually dependent relationship between religion and ethnicity'. ${ }^{19}$

\section{Populism, nationalism and religion}

Q6 Populism views politics through 'a Manichean discourse that divides politics and society as the struggle between two irreconcilable and antagonistic camps: the people and the oligarchy or the power block'. ${ }^{20}$ 'The people' is considered to be pure and undivided, yet a powerless political community full of social and political grievances. 'The elites' and 'the enemies' can be made of several groups such as political, business or cultural elites, foreign states, ethnic and religious minorities, political dissidents, and international organizations. ${ }^{21}$

The discursive approach to populism systematically accounts for how populists construct the meaning of 'the people', 'the elites' and their central antagonism in politics and society. Central to the discursive approach to populism is to unearth the articulation of (or the practice of consciously bringing together) political claims and leaving selected other claims out in a bid to establish hegemonic power over naming 'the people' and 'the elites'. They achieve this hegemony by aggrandizing the historical, social and political cleavages through generalizations and a crisis-laden political discourse. ${ }^{22}$

\footnotetext{
${ }^{18}$ Annabelle Chapman, 'Where Gender Meets Nationalism,' Berlin Policy Journal-Blog (blog), 28 August 2019, https:// berlinpolicyjournal.com/where-gender-meets-nationalism/; George L. Mosse, Nationalism and Sexuality: Middle-Class Morality and Sexual Norms in Modern Europe, Reprint (Madison: University of Wisconsin Press, 1988).

${ }^{19}$ David Barry, 'Popular Perceptions of the Relationship between Religious and Ethnic Identities: A Comparative Study of Ethnodoxy in Contemporary Russia and Beyond' (Ph.D., Western Michigan University, 2012), https://scholarworks. wmich.edu/dissertations/52.

${ }^{20}$ Carlos de la Torre, 'Populism and Nationalism in Latin America,' Javnost-The Public 24, no. 4 (2 October 2017): 375-90, https://doi.org/10.1080/13183222.2017.1330731.

${ }^{21}$ Bilge Yabanci, 'The EU's Democratization and State-Building Agenda in Kosovo: An Analysis through the Fragmented Local Agency,' in An Agenda for the Western Balkans from Elite Politics to Social Sustainability, Nikos Papakostas and Nikos Passamitros (Stuttgart: ibidem-Verlag, 2015), 23-52.

${ }^{22}$ Yannis Stavrakakis, 'Discourse Theory in Populism Research: Three Challenges and a Dilemma,' Journal of Language and Politics 16, no. 4 (1 January 2017): 523-34, https://doi.org/10.1075/jlp.17025.sta; Giorgos Katsambekis, 'Constructing "the People" of Populism: A Critique of the Ideational Approach from a Discursive Perspective,' Journal of Political Ideologies 0, no. 0 (6 November 2020): 1-22, https://doi.org/10.1080/13569317.2020.1844372.
} 
Against the powerful elites, populists claim to embody the people's will as their only true representative. ${ }^{23}$ This perception leads to denial of the legitimacy of the opponents and marginalization of social dissent as a part of the elites. ${ }^{24}$ In other words, populists challenge democracy from within due to their inherent undemocratic approach towards people's will that collapses political authority and 'the people'. ${ }^{25}$ Hence, populism in power may lead to gradual regime change with hybridization of democracies. ${ }^{26}$ This undemocratic tendency inherent to populism becomes clear especially when populists capitalize on nationalism and religion.

The state-of-the-art literature draws clear conceptual boundaries between populism and nationalism. They are both discourses that construct in and out-groups. However, populism constructs 'the people' by referring to a vertical antagonism between the people (demos) at the bottom and the elites at the top. In other words, populism objects to the current distribution of power, prestige, resources, respect and sovereignty between the people and the elites in a given society. Nationalism, on the other hand, is concerned with the distinction between different ethnos and determines who is a member of a given ethnos based on geographical, linguistic, historical or other criteria. ${ }^{27}$ It identifies what differentiates one nation from the other 'within a global frame of reference'. ${ }^{28}$ Yet, since populism takes place within national contexts, i.e. the people and the elites are often constructed within the nation-state, populism and nationalism entrench each other. ${ }^{29}$ Extant studies on the articulation of populism through nationalism revealed how populists define 'the people' as the victims of multiculturalism, immigration policies, and above all, 'the elites' that support these policies. Formal citizenship and nativism make the fusion of populism and nationalism unavoidable and skews populism towards an exclusionary discourse. ${ }^{30}$ As de Cleen argues, 'when populism is exclusionary it is usually because it is articulated with exclusionary nationalism'. ${ }^{31}$ Nevertheless, the scholarship that focused on co-articulations of populism and nationalism implicitly assumed nationalism as a secular modern construct and has ignored the role of religion in defining the boundaries of the nation in several contexts. ${ }^{32}$

\footnotetext{
${ }^{23}$ Cleen and Stavrakakis, 'Distinctions and Articulations.'

${ }^{24}$ Muller, What Is Populism?

${ }^{25}$ Federico Finchelstein, From Fascism to Populism in History (California: U. of California Pr., 2019), https://www.ucpress. edu/book/9780520309357/from-fascism-to-populism-in-history; Federico Finchelstein and Nadia Urbinati, 'On Populism and Democracy,' Populism 1, no. 1 (14 September 2018): 15-37, https://doi.org/10.1163/25888072-01011001.

${ }^{26}$ Enrique Peruzzotti, 'Populism as Democratization's Nemesis: The Politics of Regime Hybridization,' Chinese Political Science Review 2, no. 3 (2017): 314-27, https://doi.org/10.1007/s41111-017-0070-2.

${ }^{27}$ Benjamin De Cleen, 'Populism and Nationalism,' in The Oxford Handbook of Populism, ed. Cristobal Rovira Kaltwasser et al. (Oxford: OUP, 2017), 343-62, https://www-oxfordhandbooks-com.ezp.sub.su.se/view/10.1093/oxfordhb/ 9780198803560.001.0001/oxfordhb-9780198803560-e-18; C.f. Rogers Brubaker, 'Populism and Nationalism,' Nations and Nationalism 26, no. 1 (2020): 44-66, https://doi.org/10.1111/nana.12522.

${ }^{28}$ Brubaker, 'Populism and Nationalism.'

Q7 ${ }^{29}$ Benjamin De Cleen and Yannis Stavrakakis, 'How Should We Analyze the Connections between Populism and Nationalism: A Response to Rogers Brubaker,' Nations and Nationalism 26, no. 2 (2020): 314-22, https://doi.org/10. 1111/nana.12575.

${ }^{30}$ Erin K. Jenne, Kirk A. Hawkins, and Bruno Castanho Silva, 'Mapping Populism and Nationalism in Leader Rhetoric Across North America and Europe,' Studies in Comparative International Development 56, no. 2 (1 June 2021): 170-96, https:// doi.org/10.1007/s12116-021-09334-9.

${ }^{31}$ De Cleen, 'Populism and Nationalism,' 12.

${ }^{32}$ On this debate J. Christopher Soper and Joel S. Fetzer, eds., 'A Theory of Religion and Nationalism,' in Religion and Nationalism in Global Perspective, Cambridge Studies in Social Theory, Religion and Politics (Cambridge: Cambridge University Press, 2018), 1-31, https://doi.org/10.1017/9781316995280.002; Rieffer, 'Religion and Nationalism'; Adrian Hastings, The Construction of Nationhood: Ethnicity, Religion and Nationalism (Cambridge University Press, 1997).
} 
Studies on the populism-religion relationship have developed in parallel but without a dialogue with the studies on the populism-nationalism relationship. To explain populism's rapport with religion, several studies argued that religion serves as an instrumentalized system of beliefs for populist discourse. Central to this conceptualization is that populists instrumentalize religion by a superficial usage of religious cues, messages and symbolical gestures. Populism as a performative political discourse can borrow and utilize religious imagery to create a morally superior notion of 'the good people', an organic community free of divisions in opposition to evil 'enemies [to be] combated as the embodiment of evil on earth'. ${ }^{33}$ Messages alluding to religious stories, such as a narrative of 'crisis' or an impending breakdown allow populist actors to convince the masses about the threat caused by the elites and the urgency of a political change. ${ }^{34}$ The populist crisis narrative is constructed on appeals alluding to religious discourse such as an apocalyptic depiction of the current situation as a moral or spiritual crisis, a fight between the 'good' and the 'evil', total degeneration under the political and social system, and a need for a saviour. ${ }^{35}$ These messages would also denigrate political competitors as morally unfit to represent the people. What populists offer as a way out from the crisis is faith in redemption and missionary politics led by a strong leader to save the people's selfesteem. ${ }^{36}$

However, there is more to the face value and superficial appropriation of religious cues in the populist discourse. Populists also often re-imagine religious belonging or identity as a building block of the native identity of 'the people. ${ }^{37}$ As Brubaker argues, religion can become 'a way of identifying and naming fundamental social groups, [and] a powerful framework for imagining community', hence answering the question 'who are we?'. ${ }^{38}$ Especially where there is one dominant religious identity, religion historically constitutes a building block of the national identity (e.g. Hindu nationalism, Catholic Polish or Orthodox Russian identity). Karpov et al. explains the fusion of ethnic and religious identity as 'ethnodoxy':

Ethnic belonging is no longer about things this-worldly, such as language, folkways, shared ancestry, and so on. It is also about a true faith that gives its bearers' existence an ultimate meaning and value. When coupled with faith, ethnos emerges as transcendentally important and valuable, regardless of the transient, earthly, socioeconomic, political, and other circumstances its members find themselves in. Moreover, when such circumstances are dismal, even catastrophic, the sacred component of ethnic identity helps group members maintain high self-esteem and positive collective self-representations. For this reason, religious definitions and redefinitions of ethnic solidarities may be in particularly high demand when in their earthly lives ethnic groups face serious social crises and/or existential threats. ${ }^{39}$

${ }^{33}$ José Pedro Zúquete, 'Populism and Religion,' in The Oxford Handbook of Populism, ed. Cristobal Rovira Kaltwasser et al. (Oxford University Press, 2017), 451.

${ }^{34}$ Benjamin Moffitt, 'How to Perform Crisis: A Model for Understanding the Key Role of Crisis in Contemporary Populism,' Government and Opposition 50, no. 02 (April 2015): 189-217, https://doi.org/10.1017/gov.2014.13.

${ }^{35}$ Andrew Arato and Jean L. Cohen, 'Civil Society, Populism and Religion,' Constellations 24, no. 3 (2017): 283-95, https:// doi.org/10.1111/1467-8675.12312.

${ }^{36}$ José Pedro Zúquete, 'On Top of the Volcano: Missionary Politics in the Twenty-First Century,' Politics, Religion \& Ideology 14, no. 4 (2013): 507-21, https://doi.org/10.1080/21567689.2013.829045.

${ }^{37}$ Brubaker, 'Between Nationalism and Civilizationism.'

${ }^{38}$ Rogers Brubaker, 'Religion and Nationalism: Four Approaches*,' Nations and Nationalism 18, no. 1 (2012): 2-20, https:// doi.org/10.1111/j.1469-8129.2011.00486.x.

${ }^{39}$ Vyacheslav Karpov, Elena Lisovskaya, and David Barry, 'Ethnodoxy: How Popular Ideologies Fuse Religious and Ethnic Identities,' Journal for the Scientific Study of Religion 51, no. 4 (2012): 642, https://doi.org/10.1111/j.1468-5906.2012. 01678.x. 
The situation that Karpov et al. describe refers to religious belonging as a key element of creating a collective meaning about the ethnos and emerges where religion played a key role in nation-building or overlaps largely with the majority's ethnic identity. This approach highlights 'the interpenetration and intertwining' of religion and nationalism ${ }^{40}$ as a 'the belief that affiliation to an ethnic group's dominant religion is essential for constructing and maintaining a group's identity'. ${ }^{41}$

Populism can subscribe to this identitarian and collective meaning making role of religion to be able to evoke a specific construction of the people. ${ }^{42}$ In such contexts, populism endorses the dominant religious affiliation of the community as a criterion to determine 'the people'. ${ }^{43}$ Rather than believing or practising faith in private life, dominant religious identity allows populists to claim the purity and indivisibility of the people. In fact, some right-wing populists re-interpret Christianity as a source of national identity and authentic culture in direct contradiction to the Muslim (migrant) identity. ${ }^{44}$ For example, populists often claim tolerance and equality principles are embedded in Christianity and hence explain authentic culture of women's and LGBT+ rights in Europe in contrast to the Islamic culture of immigrants. Roy states that for populists, religion substantiates a nostalgia for an imagined glory of the 'eternal' nation and a moral claim to citizenship rights (i.e. right to claim and possess social and economic rights). ${ }^{45}$ Brubaker calls this attitude among European right-wing populists as 'identitarian Christianism' whereby religion is 'understood in antithetical opposition to Islam' in civilizational and identitarian terms. ${ }^{46}$

The closely interwoven nature of religious identity and nation/nationalism allows populists to define the people both 'as underdogs of the elites' and 'as the nation'. Dominant faith, religious values and symbols, rituals can be used to claim shared inheritance and value system that bond the nation together hence define horizontally who belongs to the ethnos and who is an outsider. Nevertheless, the category of the people in populism is not stable but needs to be reconstructed continuously depending on the (changing) political needs. Hence, the way populists articulate religion-nationalism nexus changes across contexts and across time when validating different groups as the constituents of the people. One critical reference is the historical co-evolution of nationalism and religion in the process of nation-building. It constitutes the backbone of contemporary populism's construction of the people where only some groups are the real people. ${ }^{47}$

\footnotetext{
${ }^{40}$ Brubaker, 'Religion and Nationalism.'

${ }^{41}$ Barry, 'Popular Perceptions of the Relationship between Religious and Ethnic Identities.'

${ }^{42}$ Andrew Arato, 'Political Theology and Populism,' Social Research: An International Quarterly 80, no. 1 (2013): 143-72; Bilge Yabanci, 'Fuzzy Borders between Populism and Sacralized Politics: Mission, Leader, Community and Performance in "New" Turkey,' Politics, Religion \& Ideology 21, no. 1 (2 January 2020): 92-112, https://doi.org/10.1080/21567689. 2020.1736046.

Q8 ${ }^{43}$ Bilge Yabanci and Dane Taleski, 'Co-Opting Religion: How Ruling Populists in Turkey and Macedonia Sacralise the Majority,' Religion, State and Society 46, no. 3 (2018): 283-304, https://doi.org/10.1080/09637494.2017.1411088; Dani Filc, 'We Are Also the (Chosen) People, You Are Not,' in Saving the People, ed. Nadia Marzouki (London: Hurst \& Company, 2016); András Bozóki and Zoltán Ádám, 'State and Faith: Right-Wing Populism and Nationalized Religion in Hungary,' Intersections. East European Journal of Society and Politics 2, no. 1 (2016): 98-122, https://doi.org/10.17356/ ieejsp.v2i1.143.

${ }^{44}$ Arato and Cohen, 'Civil Society, Populism and Religion'; Marzouki, McDonnell, and Roy, Saving the People.

${ }^{45}$ Olivier Roy, 'Beyond Populism,' in Saving the People, ed. Nadia Marzouki, Duncan McDonnell, and Olivier Roy (London: Hurst, 2016), 185-202.

${ }^{46}$ Brubaker, 'Between Nationalism and Civilizationism,' 1194.

${ }^{47}$ Jan-Werner Müller, '“The People Must Be Extracted from Within the People": Reflections on Populism,' Constellations 21, no. 4 (2014): 483-93, https://doi.org/10.1111/1467-8675.12126.
} 
From the intermingling of religion and national/ethnic identity, populists can construct several parallel and at times conflicting versions of 'the people versus elites' antagonism. By entangling religion and nationalism, they can bind various grievances of different groups against the allegedly oppressive economic, cultural and political elites. ${ }^{48}$

\section{Research design and methodology}

In line with the discursive approach to populism, this study draws upon a qualitative design and analyses the political discourse of the AKP. Discourse analysis refers to 'the close study of language and language use as evidence of aspects of society and social life'. ${ }^{49}$ Discourse theory argues that written and spoken arguments are not empty talks but represent authority, entitlement and social acceptability, and legitimize power and policies. ${ }^{50}$ Critical Discourse Analysis (CDA) is specifically concerned with the connections between language use and 'dominance relations' by examining how discourse reproduces 'social power by elites, institutions or groups, that results in social inequality, including political, cultural, class, ethnic, racial and gender inequality'. ${ }^{51}$ Discourse is not just the language or expression, but the interpretation of what is 'right' and acceptable from a particular point of view. ${ }^{52}$ The production and control of discourse leads to the exercise of social control, reproduction of domination and hegemony. ${ }^{53}$ Once a particular piece of information is embedded in the public memory with negative content, through various discursive cues, dominant political actors can utilize that negative public memory and prevent the adoption or internalization of alternative discourses that may be postulated on that subject. The internalization of this particular discourse by the wider public means that powerful political actors have the ability to persuade and manipulate a particular society. Therefore, through discourse analysis, one can establish how discourse benefits certain groups, establishes 'the truth' that becomes a dominant ideology. $^{54}$

In this study, discourse is defined as 'the talk or language of a particular speaker or source' and focus on 'public discourse' that are addressed to the public audience in Turkey by the AKP. ${ }^{55}$ Party programme, parliamentary debates, speeches by high-level representatives of political parties and governments, election campaign talks and other types of collective speech and text by political actors constitute the AKP's political discourse. Discourse analysis is used to reveal discursive practices and constructions of the populist antagonism of 'us, the people' versus 'them, the elites and enemies' or more clearly, the boundaries of the political imagination of the people and the role of religion and nationalism in this populist discourse. This imagination opens the way for the legitimization of coercive policies and power relations vis-à-vis certain groups. The study benefits

\footnotetext{
${ }^{48}$ Vedi R. Hadiz, 'A New Islamic Populism and the Contradictions of Development,' Journal of Contemporary Asia 44, no. 1 (2014): 125-43, https://doi.org/10.1080/00472336.2013.832790.

${ }^{49}$ Stephanie Taylor, What Is Discourse Analysis? (London: Bloomsbury Academic, 2012).

${ }^{50}$ van Dijk, 'Principles of Critical Discourse Analysis.'

${ }^{51}$ van Dijk, 249.

${ }^{52}$ N Fairclough, Ruth Wodak, and Teun A. van Dijk, 'Critical Discourse Analysis,' in Discourse Studies: A Multidisciplinary Introduction, Vol. 2, Discourse as Social Interaction (London: Sage, 1997), 258-84.

${ }^{53}$ Teun A. van Dijk, 'Discourse, Ideology and Context,' Folia Linguistica 35, no. 1-2 (2001): 11-40, https://doi.org/10.1515/ flin.2001.35.1-2.11.

${ }^{54}$ Dijk.

${ }^{55}$ Taylor, What Is Discourse Analysis?
} 
largely from the literature on the discursive construction of prejudice and racism towards minority groups. This body of research showed how arguments and language practices can rationalize and perpetuate social inequalities and attribute a negative value to certain groups or categories of people by relying on social taboos and culture. ${ }^{56}$

Public speeches of high-ranking AKP politicians and advisors, parliamentary talks, statements made for the media and electoral campaigns in both spoken and written language have been analysed for revealing the meaning, motives, opinions and purposes embedded within the discourse. Due to the personalistic style of populism in Turkey, the speeches of Erdoğan were given particular priority. Erdoğan's public discourse has clearly a political and social relevance as 'appropriate and authoritative' not only because he is a focal figure in politics but also his discourse is often copied by the AKP, civil society and even the opposition ranks. ${ }^{57}$ The analysis has yielded inductive categories whereby religious and nationalist discourse, policies and imagery have constructed three different, and at times, contradictory articulations of 'the people' where Islam has served a key role: 'the people as underdogs', 'people as nation' and 'people as the ummah' against 'the secular elites', 'the enemies within' and 'the West'. ${ }^{58}$

\section{Prelude: the shadow the nationalist-conservative ideology}

This section analyses how religion has become an integral aspect of modern state and nationalism in Turkey and provide the crucial historical background for understanding contemporary populism. The fusion of nationalism, religion and identitarian civilizationism-shaped Turkey's transition from a multi-national and multi-religious empire to a nation-state in the late $19^{\text {th }}$ and early $20^{\text {th }}$ centuries. Three interlinked historical processes provide the background for the contemporary populist politics in Turkey: 1) modernization in the late 19th and early 20th century, 2) the rise of Turkish nationalism with an 'anti-Western' core after the turbulent years of the Ottoman disintegration, 3) the nationalist-conservative intellectual tradition.

In the $19^{\text {th }}$ century, the Ottoman Empire's initial response to nationalist fervour was the promotion of 'Ottomanism' under Sultan Abdulhamit II. It aimed to prevent non-Muslims (that still constituted $40 \%$ of the population) from seeking independence by constructing an overarching Ottoman identity above and over ethnic and religious group identities. ${ }^{59}$ When Ottomanism failed to prevent non-Muslim groups' from seeking independence, it was replaced by 'proto-Islamism' to keep ethnically diverse Muslim subjects together. ${ }^{60}$

\footnotetext{
${ }^{56}$ Jenny Cheshire and Peter Trudgill, eds., The Sociolinguistics Reader: Volume 2: Gender and Discourse (London; New York : New York: Routledge, 1997); Margaret Wetherell and Jonathan Potter, Mapping the Language of Racism: Discourse and the Legitimation of Exploitation, Mapping the Language of Racism: Discourse and the Legitimation of Exploitation (New York, NY, US: Columbia University Press, 1992); Jovan Byford, 'Distinguishing "Anti-Judaism" from "Antisemitism": Recent Championing of Serbian Bishop Nikolaj Velimirović,' Religion, State and Society 34, no. 1 (2006): 7-31, https://doi. org/10.1080/09637490500459867; Luisa Martín Rojo and Teun A. van Dijk, "'There Was a Problem, and It Was Solved!": Legitimating the Expulsion of 'Illegal' Migrants in Spanish Parliamentary Discourse,' Discourse \& Society 8, no. 4 (1997): 523-66, https://doi.org/10.1177/0957926597008004005.

${ }^{57}$ Yabanci, 'Fuzzy Borders between Populism and Sacralized Politics.'

${ }^{58}$ I borrow the labels 'people as underdogs' and 'people as nation' from De Cleen, 'Populism and Nationalism.'

${ }^{59}$ Gökhan Çetinsaya, 'Rethinking Nationalism and Islam: Some Preliminary Notes on the Roots of "Turkish-Islamic Synthesis" in Modern Turkish Political Thought,' The Muslim World 89, no. 3-4 (1999): 350-76, https://doi.org/10. 1111/j.1478-1913.1999.tb02753.x.

${ }^{60}$ Haldun Gülalp, 'Using Islam as Political Ideology: Turkey in Historical Perspective,' Cultural Dynamics 14, no. 1 (2002): 21-39, https://doi.org/10.1177/09213740020140010201.
} 
Çetinsaya argues that during this period, 'Islam was regarded as a social cement, a source of solidarity or national unity, and an element of common citizenship' for the Muslim population. ${ }^{61}$ Although proto-Islamism was a pragmatic response to prevent the breakdown of the empire, it 'relegat[ed] adherents of other religions to a secondary, inferior status $^{62}$ and justified forced migration and genocide of non-Muslim subjects later on. ${ }^{63}$

During the $20^{\text {th }}$-century nation-building process, mainstream Turkish nationalism was shaped by this early fusion of national and religious identity. Islam was given a new cultural and civilizational interpretation with a modernist lens. ${ }^{64}$ The founding elites of the republic perceived the transcendental religious doctrine of Islam as 'a symbol of obscurantism' and occupied themselves with 'modernizing' it in line with what was claimed to be a national/ethnic tradition. ${ }^{65}$ It was also believed that the rebirth of the Turkish state as a modern republic would engender a revival for the Islamic world at large by setting an example. Towards this end, the early republican intellectuals and lawmakers welded promoted Westernization of Turks as Muslims. One of the leading intellectual figures of the era Ziya Gökalp's formula exemplifies this alliance: 'I am a member of the Turkish nation, the Islamic community and Western civilization'. ${ }^{66}$

This understanding of religion through ethnicity promoted ethnodoxy that rigidly linked Turkish ethnic identity to the dominant religion and consequently perceived other religious groups 'as potentially or actually harmful to the group's unity and wellbeing'. ${ }^{67}$ Ethnodoxy was adopted in Turkey's nation-building for two reasons. First, it was akin to the embedded historical understanding of ethnic communities with their religious affiliations under the Ottoman millet system. ${ }^{68}$ Second, the military and political humiliation in WWI and the subsequent occupation engraved an omnipresent distrust towards the West ${ }^{69}$ that encouraged adoption of official Turkish Islam as a signifier of authentic national identity.

Against this backdrop, a new generation of intellectuals who labelled themselves as 'nationalist-conservative' emerged in the 1950s onwards and promoted the fusion of nationalism and Islam further. ${ }^{70}$ They defended top-down social engineering of society, especially the youth, to prevent what is deemed to be 'degeneration' under the Western influence and the penetration of communism. ${ }^{71}$ They also praised anti-Western and anti-Semitic conspiracy and revisionism ${ }^{72}$ and lamented

\footnotetext{
${ }^{61}$ Çetinsaya, 'Rethinking Nationalism and Islam,' 352.

${ }^{62}$ van der Veer, Religious Nationalism, 23.

${ }^{63}$ Ronald Grigor Suny, Fatma Müge Göçek, and Norman M. Naimark, A Question of Genocide: Armenians and Turks at the End of the Ottoman Empire, 1st ed. (Oxford: OUP, 2011).

${ }^{64}$ Andrew Davison, 'Secularization and Modernization in Turkey: The Ideas of Ziya Gökalp,' Economy and Society 24, no. 2 (1995): 189-224, https://doi.org/10.1080/03085149500000008.

${ }^{65}$ Nazım İrem, 'Turkish Conservative Modernism: Birth of a Nationalist Quest for Cultural Renewal,' International Journal of Middle East Studies 34, no. 1 (2002): 87-112.

${ }^{66}$ Çetinsaya, 'Rethinking Nationalism and Islam,' 355.

${ }^{67}$ Karpov, Lisovskaya, and Barry, 'Ethnodoxy.'

${ }^{68}$ Sener Akturk, 'Persistence of the Islamic Millet as an Ottoman Legacy: Mono-Religious and Anti-Ethnic Definition of Turkish Nationhood,' Middle Eastern Studies 45, no. 6 (2009): 893-909, https://doi.org/10.1080/00263200903294229.

${ }^{69}$ Erik J. Zurcher, The Young Turk Legacy and Nation Building: From the Ottoman Empire to Ataturk's Turkey (London ; New York: New York: Tauris Academic Studies, 2010).

${ }^{70}$ Mümtazer Türköne, İslâmalığın Doğuşu [The birth of Islamism] (Istanbul: lletisim, 1994).

${ }^{71}$ Yuksel Taskin, Milliyetçi Muhafazakâr Entelijansiya [Nationalist-Conseervative Intelligentsia] (Istanbul: Iletisim, 2007).

${ }^{72}$ Tanıl Bora, Türkiye'de Siyasî Ideolojiler [Political Ideologies in Turkey] (Istanbul: lletisim, 2017).
} 
over the Ottoman Empire's lost hegemony. ${ }^{73}$ Turkey's political Islamist parties have empowered themselves out of this intellectual line from the 1960 s onwards. ${ }^{74}$ Due to the secular state's suspicion of 'unofficial' Islamic influences from abroad as a potential challenger of the secular republican regime, the mainstream Turkish Islamism has grown not against but out of the state tradition that defines Islam in cultural terms as a part of Turkish national identity. ${ }^{75}$ Indeed, both nationalists and Islamists capitalized on similar intellectual sources and collective historical traumas rooted in the disintegration of the Ottoman Empire in the 19th century. They were also united under an intellectual centre 'Aydınlar Ocağı' (literally means Hearth of Intellectuals) which advocated Islam as a tool of social control whereby individuals would be moulded to become good citizens and learn not to challenge the secular basis of the state and reject leftist or radical Islamist ideology. ${ }^{76}$

The nationalist-conservative circles whipped the already-existing anti-Western scepticism. While they criticized, the early republican regime for denying the inheritance of 'a glorious imperial past', 'the authentic Muslim Turk [was] portrayed as the epitome of resistance to alienation, loss of one's true identity and ... 'auto-colonization'. In this framework, 'the archenemy' has become 'the westernized, Europeanized and therefore "alienated" Turkish elite and intelligentsia' ${ }^{77}$ Pro-Western groups and minorities were deemed 'enemies' and 'traitors' inside who work against the nation's attempt at saving its spirit and cherishing its own and superior culture against 'the impending danger of total colonization'. ${ }^{78}$

Until the 1980 coup, these ideas remained mostly within the Aydınlar Ocağı. The military junta institutionalized, it as a state policy known as Turkish-Islam synthesis ${ }^{79}$ to counteract both the resurfacing of the far-left movements and the radical Islamist waves from the Middle East. ${ }^{80}$ In the post-1980, the Turkish-Islam synthesis found substance in the state-controlled circulation of religious values. During the 1980s and 1990s, Turkey witnessed compulsory religious teaching at public schools, the expansion of religious schools and Quran courses. Islam was promoted, albeit controlled and moderated, as a central constituent of Turkish culture and identity reaffirming ethnodoxy. The recipe of Turkish-Islam was considered as a panacea both against the more radical political Islam and far-left movements well until the beginning of the 2000 s.

\footnotetext{
${ }^{73}$ Güven Gürkan Öztan, 'Türk Sağında Devlet Fetişizmine Dair [On State Fetishism in Turkish Right],' in Türk Sağı: Mitler, Fetişler, Düşman Imgeleri, ed. İnci Özkan-Kerestecioğlu and Güven Gürkan Öztan (Istanbul: Iletisim, 2012), 425-58.

${ }^{74}$ Çetinsaya, 'Rethinking Nationalism and Islam.'

${ }^{75}$ Çetinsaya.

${ }^{76}$ Erkan Akin and Omer Karasapan, 'The "Turkish-Islamic Synthesis,"' Middle East Report, no. 153 (1988): 18-18, https://doi. org/10.2307/3012127.

${ }^{77}$ Nergis Canefe and Tanıl Bora, 'The Intellectual Roots of Anti-European Sentiments in Turkish Politics: The Case of Radical Turkish Nationalism,' Turkish Studies 4, no. 1 (2003): 127-48, https://doi.org/10.1080/714005725.

${ }^{78}$ Canefe and Bora.

${ }^{79}$ Conservative intellectuals played a key role in the development of this idea, especially Ibrahim Kafesoglu, Turk Islam Sentezi (İstanbul: Ötüken Nesriyat, 1985); See review by Taskin, Milliyetçi Muhafazakâr Entelijansiya [NationalistConseervative Intelligentsia]; S. Erdem Aytaç and Ezgi Elci, 'Populism in Turkey,' in Populism Around the World, ed. D. Stockemer (Springer, Cham, 2018), 89-108.

${ }^{80}$ Bora, Türkiye'de Siyasî İdeolojiler [Political Ideologies in Turkey], 403.
} 


\section{AKP, religion and populism}

The intertwined features of religion, nationalism and right-wing intellectual tradition has preceded the AKP's stance on populism. The AKP not only claimed a historical political tradition but also skilfully tailored this long historical tradition from an intellectual-elite tradition into a hegemonic discourse to establish a populist authoritarian dominance. The AKP's versatile populist discourse redefined 'the people' and 'the elites' dichotomy several times changing groups or individuals that fall into the people or elite groups. During the AKP's earlier years the conception of the 'people as underdogs' against secular state elites dominated the AKP's populism signifying a more inclusionary stance, whereas later on with gradual democratic backsliding, 'people as nation' and 'people as the ummah' have become more accentuated.

\section{'People as underdogs': Islam as the overarching identity of the people against secular elites}

During its early years in power, Islam's role in the AKP's inclusionary populism can be likened to the proto-Islamism of the 19th century Ottoman Empire. When the AKP came to power, it sought to redefine the secular-ethnic basis of Turkish national identity. From the beginning, the AKP adopted a populist discourse accusing the republican and secular Kemalist elites of not representing the interests of the ordinary people and promised to bring under-represented citizens to the centre.$^{81}$

In so doing, the AKP referred to Islam as a common denominator of 'the people' including not only the conservative, pious and rural segments of society, but also non-Sunni and nonTurkish groups under the common Islamic culture. During the first (2002-2007) and second (2007-2011) AKP terms, the party leadership's public discourse involved several promises of 'restoring the ancient togetherness' of the people. ${ }^{82}$ The public discourse regarding 'the people' as a unified bloc against the wrongdoings of the secular republican elites aimed to incorporate the Alevi ${ }^{83}$ and Kurdish minorities into the body of 'the people'. In both cases, the AKP utilized discursive cues and messages to generate the unity of the people around the common Islamic identity to unite these historically marginalized groups.

\section{The Alevi initiative}

Alevis, as a syncretic religious group, had a turbulent history of persecution since the Ottoman Empire. Their belonging and loyalty were also questioned by nationalists and Islamists under the republic. ${ }^{84}$ In 2007, the AKP presented the Alevi Initiative to show commitment to democratic reforms. Despite having a dominantly religious Sunni-Hanafi electorate, the AKP embraced a public discourse emphasizing the common culture and

\footnotetext{
${ }^{81}$ Şakir Dinçşahin, 'A Symptomatic Analysis of the Justice and Development Party's Populism in Turkey, 2007-2010,' Government and Opposition 47, no. 4 (2012): 618-40, https://doi.org/10.1111/j.1477-7053.2012.01377.x.

${ }^{82}$ Ahmet Davutoglu, 'The Great Restoration,' Republic of Turkey Ministry of Foreign Affairs, 2013, http://www.mfa.gov.tr/ disisleri-bakani-ahmet-davutoglu_nun-diyarbakir-dicle-universitesinde-verdigi-_buyuk-restorasyon_-kadim_denkuresellesmeye-yeni.tr.mfa.

${ }^{83}$ Alevis are a religious minority group that practices a heterodox Islam combining Shia Islam and several syncretistic elements. Historically, under the Sunni-majority rule, they have faced periodical assimilation, persecution and violence.

${ }^{84}$ Zurcher, The Young Turk Legacy and Nation Building; Elise Massicard, The Alevis in Turkey and Europe: Identity and Managing Territorial Diversity, 1 edition (London; New York: Routledge, 2012); Mehmet Bardakci et al., 'The Alevi, the AKP Government and the Alevi Initiative,' 2017, 97-131, https://doi.org/10.1057/978-1-137-27026-9_4.
} 
centuries of coexistence between the Alevi and Sunni communities. This move was motivated and legitimated by the AKP's early populism targeting the secular Kemalist establishment. Erdoğan's statement from 2008 summarize the government's approach to Alevis under Islam's unifying overarching identity:

I am here to share our common mourning. We have been drinking from the same spring; we have been turning to the Mecca [to pray], we should not blame each other for what happened in the past ${ }^{85}$

Erdoğan tried to convey a message of unity and solidarity based on the common religion. Similarly, an adviser to Erdoğan argued that 'what unites Alevis and Sunnis in Turkey is more than what divides them, ${ }^{86}$ From the perspective of discourse theory, the AKP attempted to establish 'a new truth' in order to define the ingroup and manufacture consensus about who belongs to it based on the common antagonism to the Kemalist establishment and common religious belonging. The reference to 'our common mourning' and unity under one religion aimed to downgrade differences by incorporating Alevis into the overarching Islamic identity. The AKP's discourse also promoted a new page in the relations between Alevis and the Sunni-dominant ideology of the state. Although Erdoğan's words 'we should not blame each other for what happened in the past' admit past wrongdoings, it avoided acknowledging the history of the discrimination and group violence that targeted Alevis.

More importantly, the AKP's discourse aimed to co-opt Alevis as a group in the category of 'the people as underdogs'. The government sought to impose its own interpretation of Alevism. In this imagination, Alevis would be melded and 'tolerated' within Sunni-Islam. Erdoğan declared himself as an Alevi by defining 'Alevism as the love of Ali'. As a part of the initiative, the AKP convened seven Alevi workshops. Nevertheless, Sunni theologians and intellectuals dominated these workshops whereas critical Alevi organizations were excluded. ${ }^{87}$ Besides the symbolic gestures of visiting cemevis (Alevi sites for religious practice), visiting dominantly Alevi towns, attending Alevi commemorations by high-ranking AKP representatives, Alevi's core demands for equal status, recognition as a distinct faith, legal recognition for cemevis and religious leaders (dede) and exemption from compulsory Sunni-Islam classes at schools were effectively dismissed. ${ }^{88}$ The AKP proposed 'Alevi Directorate' under the Prime Minister's office to control and fund cemevis by directly appointing Alevi religious authorities under the Diyanet, the highest religious authority controlled by the state.

While the Alevi Initiative was unfolding through Alevi workshops between 2009 and 2011, the government's public discourse was inconsistent. During the 2010 constitutional referendum campaign, Erdoğan pejoratively mentioned the Alevi identity of the main opposition party leader Kemal Kılıçdaroğlu during electoral rallies, and in the 2011 general elections that marked the AKPs transition to majoritarianism and undemocratic practices, the pro-Alevi discourse was completely dropped from the AKP's agenda. Overall, public

\footnotetext{
${ }^{85}$ Radikal, 'Erdoğan'dan Alevilere: Acıyı Bal Eyleyelim ..., ' January, 12, 2008, http://www.radikal.com.tr/haber.php? haberno=244199.

${ }^{86}$ Ibrahim Kalin, 'Will the Alevi Initiative Share the Destiny of the Kurdish Initiative?,' 17 January 2008, https://www.setav. org/en/will-the-alevi-initiative-share-the-destiny-of-the-kurdish-initiative/.

${ }^{87}$ Bardakci et al., 'The Alevi, the AKP Government and the Alevi Initiative.'

${ }^{88}$ Murat Borovalı and Cemil Boyraz, 'Turkish Secularism and Islam: A Difficult Dialogue with the Alevis,' Philosophy \& Social Criticism 40, no. 4-5 (2014): 479-88, https://doi.org/10.1177/0191453714522476.
} 
discourse surrounding the government's Alevi policy re-instigated long-standing fears of assimilation. ${ }^{89}$ Workshops organized by the government were eventually boycotted by the major Alevi organizations that interpreted the government's discourse as an apparent attempt to end the autonomy of Alevism without recognizing, Alevis' distinct identity and rights.

The Kurdish initiative

The government adopted a similar approach concerning the Kurdish question and sought to address a complicated political issue by redefining 'people' to include Kurds in the unified people bloc. The Kurdish initiative was announced in 2009. The AKP sought to redefine the Kurdish issue away from the security-dominated political discourse towards the shared religion and the Ottoman past between Kurds and Turks. The initiative was soon renamed as 'the national unity and brotherhood project' (milli birlik ve kardeşlik) by Erdoğanhoping that common religious identity among Turks and Kurds would initiate reconciliation by integrating Kurds in the 'the people as underdogs' against the secular and Kemalist establishment. ${ }^{90}$ Until June 2015, the AKP continued to refer to the Kurdish initiative as a project to 'reinforce brotherhood' and 'reassert the dominance of popular will and national unity'.

Towards this end, the pro-AKP media and intellectuals were quick to resuscitate the Ottoman policy of classifying the population according to religious belonging (millet system) as a potential solution to the Kurdish issue. ${ }^{91}$ The AKP has sought to strengthen common belonging (ortak aidiyet bilincinin güçlendirilmesi) through emphasizing history and citizenship. Political discourse has focused on Ottoman and Seljuk era wars, referring to Islamic ideas such as martyrdom and common prayers. Erdoğan words are exemplary of the government's discourse: 'There is a very serious mistake here. Although the mother in the east and the mother in the west recite the same Fatiha, the same Yasin at the grave of their young offspring, lament the same way, although the congregation (cemaat) turn to the same qibla, these sufferings continue'. ${ }^{92}$

Another discursive strategy was to draw parallels between the Kurds who suffered under ethnic nationalism and Muslims who suffered under the secularism of the Kemalist establishment. During an election rally in Diyarbakir, Erdoğan addressed the crowds in the following words:

Everything denied to you was denied to us as well. Mosques were converted into barns and warehouses by the CHP. The same party also banned religious books. I, your brother, was imprisoned for reading a poem in Siirt. I have heard the outcry of Diyarbakir prison from Istanbul. I fight for the same thing. I know very well what denial and assimilation are. Both are over. I know the tears of a [Kurdish] mom who cannot speak with his son in her language at Diyarbakir prison. ${ }^{93}$

\footnotetext{
${ }^{89}$ Esra Özyürek, "'The Light of the Alevi Fire Was Lit in Germany and Then Spread to Turkey": A Transnational Debate on the Boundaries of Islam,' Turkish Studies 10, no. 2 (2009): 233-53, https://doi.org/10.1080/14683840902864028.

${ }^{90}$ Cumhuriyet, '"Milli Birlik Projesinin Gereği,"' 2009, http://www.cumhuriyet.com.tr/haber/diger/95190/_Milli_birlik_pro jesinin_geregi_html.

${ }^{91}$ Mustafa Akyol, 'Kürt Sorununu Çözmek İçin Osmanlı Tecrübesini Hatırlamak Gerek [We Need to Remember the Ottomon Heritage to Solve the Kurdish Problem],' Köprü Bahar, no. 98 (2007), http://www.koprudergisi.com/index.asp?Bolum= EskiSayilar\&Goster $=$ Yazi\&YaziNo $=840$.

${ }^{92}$ Erdoğan's AKP party group speech, 3 October 2019.

${ }^{93}$ Cenk Saraçoğlu, 'İslami-Muhafazakar Milliyetçiliğin Millet Tasarımı: AKP Döneminde Kürt Politikası [Imagination of Nation by Islamic-Conservative Nationalism: Kurdish Policy during the AKP Era],' Praksis 26, no. 2 (2011): 31-54.
} 
Clearly, Erdoğan's choice of language aimed to construct 'the people' according to religious and cultural identity in order to deny republican elites' state policy. Kurds were considered to be a natural ally of the conservative-religious-Islamist groups as the underdogs of the secular state.

Moreover, the AKP also identified individuals and groups supportive of the AKP's Kurdish policy on the side of peace, while critics of the policy were referred 'the enemies of peace, the nation and the state'. ${ }^{94}$ In a party speech, Erdoğan argued that: 'we are in search of a common language, a common mindset [with Kurds]. We seek a solution through common wisdom. Unfortunately, they say 'we do not support common language and common mindset'. ${ }^{95}$ Yet, in another statement, the President asserted that 'it bothers them that Turkey will leave this problem behind and move forward to the future as a big and strong country. ${ }^{.}{ }^{96}$ The choice of language and words unveil how the Kurdish initiative shaped to delimit 'us' and 'them, the elites and enemies'. The vague references to 'they/them' collapse several distinct groups into the same category of 'the elites', including the secular Kemalist establishment that dominated state bureaucracy and the army and the opposition who rejected the Kurdish initiative on securitized grounds. ${ }^{97}$

An important dimension of the discourse surrounding the Kurdish initiative is the insistence on its native and authentic (yerli ve milli) nature conducted in the name of the people. The then Prime Minister Davutoğlu claimed that the initiative was not undertaken 'in the name of an ethnic group against another one'. ${ }^{98}$ Throughout 2009, during the parliamentary speeches and party group talks, Erdoğan nominated the AKP as the 'only actor' that could absolve Turkey from the Kurdish issue, and do it in the name of the people to save Turkey's integrity and elevate it (Türkiye'yi ayağa kaldırma). ${ }^{99}$ The AKP era and its approach to the Kurdish issue were depicted as a 'new epoch' in contrast to preAKP Turkey. This claim aimed also to reject the PKK's (Partîya Karkerên Kurdistanê-an armed Kurdish insurgent group, considered a terrorist organization by Turkey)- and proKurdish political parties' (BDP/HDP) claims to represent Kurds.

In the end, Alevi and Kurdish initiatives were a move to construct and expand 'the people' against the establishment. The utilization of Islam as a common identity framework enabled the AKP to expand 'the people' beyond its traditional support base. This was a modern interpretation of the 19th-century proto-Islamist nationalism; and just like proto-Islamism, it effectively sought to prevent pluralistic definitions of 'the people' from gaining political significance. It sought to redefine the hegemonic discourse away from not only the securitized discourse of previous governments that the AKP labelled as elites but also the long-standing claim for equality and recognition in favour of the unity and homogeneity of the people under Islam.

\footnotetext{
${ }^{94}$ Erdoğan's AKP party group speech, 1 December 2009.

${ }^{95}$ Erdoğan's AKP party group speech, 11 August 2009.

${ }^{96}$ Erdoğan's AKP party group speech, 13 October 2009.

${ }^{97}$ Issmet Parlak and Armağan Öztürk, '2009-2015 Aralığında Açılım Süreçlerine Yönelik Siyasi Parti Söylemleri [Political

Party Discourses on Initiatives between 2009-2015],' LAÜ Sosyal Bilimler Dergisi 6, no. 2 (2015): 87-114.

${ }^{98}$ Erdoğan's AKP Party Group speech, 2 March 2015.

${ }^{99}$ Erdoğan's AKP group speech on 11.08.2009.
} 


\section{'People as nation': Ethnodoxy to determine the 'deserving' people}

Initially, the AKP sought to expand the people category to include historically marginalized ethnic and religious minorities. Following the third electoral victory in 2011, the AKP updated the people and the elites antagonism during this period of building political hegemony. This turn can be explained by two factors. The first is related to 'the chameleonic nature' of populism. ${ }^{100}$ Populism as an essentially anti-elite and anti-establishment discourse does not bode well with being in power. Populists come to power by criticizing the system and the elites, depicting themselves as outsiders untainted by the system. However, once the old establishment is discarded, a populist movement or actor has to 'continuously demonstrate the relevance of its anti-establishment claims' which requires redrawing the boundaries of us and them by including new groups into 'the people' and, if needed, excluding groups and 'constructing' new elites and enemies. ${ }^{101}$

The second factor is related to the internal dynamics of the AKP and Turkish politics. After the 2010 constitutional referendum and 2011 electoral victory, the AKP entrenched its political power thanks to its alliance with the Gülen Movement. ${ }^{102}$ It discarded the Kemalist secular establishment from the judiciary and the bureaucracy and increasingly turned to monopolistic and undemocratic practices. ${ }^{103}$ The autocratic tendencies of the AKP created widespread dissent and culminated into countrywide protests in 2013. Gezi Protests did not only create a long-lasting social memory of resistance against populist authoritarian rule in Turkey but also dismantled the previous cross-class and crosscleavage alliance (including liberals, Kurds, business groups, ex-Islamists) that backed the AKP. As a result, the AKP has found itself amid a need to redefine the borders of 'the people'. The nodal point of the new antagonism has become 'the people as nation'.

This updated form of populist construction of 'the people' was largely built on the nationalist-conservative tradition of the 1960s-70s. 'The people as nation' was delineated by asserting the moral superiority of the Turkish-Muslim people over 'the enemies inside'. The AKP gave up on referring to Islam as a unifying force that crosscuts ethnic and sectarian lines but as an exclusionary and boundary-making identity marker for the 'true Turks'. The concrete indication of the new relationship between populism, nationalism and religion is the post-2015 alliance between the AKP and MHP -the far-right ultranationalist party ${ }^{104}$ and the gradual dissolution of the Kurdish and Alevi initiatives.

The signs of ethnodoxy in populist discourse appeared at the political discourse level earlier. The flagship new motto of the AKP has become 'one state, one nation, one flag, and one religion.. ${ }^{105}$ Minority ethnic and religious identities of the opponents were

\footnotetext{
${ }^{100}$ Paul Taggart, Populism. Concepts in the Social Sciences (Buckingham: Open University Press, 2000).

${ }^{101}$ Bilge Yabanci, 'Populism as the Problem Child of Democracy: The AKP's Enduring Appeal and the Use of Meso-Level Actors,' Southeast European and Black Sea Studies 16, no. 4 (2016): 591-617, https://doi.org/10.1080/14683857.2016. 1242204.

${ }^{102}$ M. Hakan Yavuz, 'A Framework for Understanding the Intra-Islamist Conflict Between the AK Party and the Gülen Movement,' Politics, Religion \& Ideology 19, no. 1 (2018): 11-32, https://doi.org/10.1080/21567689.2018.1453247.

${ }^{103}$ Kerem Öktem and Karabekir Akkoyunlu, Exit from Democracy: Illiberal Governance in Turkey and Beyond (Oxon: Taylor \& Francis Group, 2017); Yunus Sözen, 'Populist Peril to Democracy: The Sacralization and Singularization of Competitive Elections,' Political Studies Review 17, no. 3 (2019): 267-83, https://doi.org/10.1177/1478929918814613; Ergun Özbudun, 'AKP at the Crossroads: Erdoğan's Majoritarian Drift,' South European Society and Politics 19, no. 2 (2014): 155-67, https://doi.org/10.1080/13608746.2014.920571.

${ }^{104}$ Kemal Can and Tanıl Bora, Devlet Ocak Dergâh (Istanbul: Iletisim, 1991).

${ }^{105}$ Presidency Office, 'Yes for One Nation, One Flag, One Homeland, One State,' 2017, https://www.tccb.gov.tr/en/news/ 542/70984/tek-millet-tek-bayrak-tek-vatan-tek-devlet-icin-evet.html.
} 
evoked several times to delegitimize and marginalize dissent or to assert one's true belonging to the nation. To exemplify, AKP representatives, particularly Erdoğan, denounced the main opposition party's leader by stating his Alevi identity ('you know he is Alevi') on several occasions. In 2014, Erdoğan also complained that smear campaigns had targeted him by claiming that he is Armenian ('they have called me ugly things, such as I beg your pardon, that I am Armenian'). More clearly, the AKP has asserted itself as the only actor to restore the authentic morals and traditions of 'our superior civilization' and build the future on the model of the past. This is an attempt at authoritarian social engineering akin to what nationalist-conservative intellectual tradition promoted to 'purify the society from the "contaminating" effects of Westernization'. ${ }^{106}$ Groups who do not identify as Turks and Sunni-Muslims, dissidents and 'faithless' are all deemed to be of the same origin, whose civic rights of citizenship could be suspended or denied at will. The AKP's resort to ethnodoxy has found its concrete substance through the public discourse on a) youth, and b) women, gender and family.

\section{'15 July youth' versus the 'Gezi youth'}

After the April 2017 constitutional referendum that sealed the regime change and introduced the executive presidential system, Erdoğan delivered a speech at a progovernment youth foundation's annual meeting stating that 'the heroes of 15 July were youngsters. They love their motherland and nation. They fought the putschist traitors. Those were not the Gezi Park youngsters. They were on the streets for the flag and prayer' .${ }^{107}$ The 'pious youth and rebellious Gezi youth' antagonism reflects the broader transformation of the AKP's populism from people as underdogs to people as nation. Two years later, Erdoğan described the 15 July youth in more detail by melding nationalist and Islamic cultural symbols and references: discourse on a) youth, and b) women, gender and family.

As exemplified from these statements, the youth occupies an extensive space in the public discourse. Erdoğan's depictions of the ideal youth always blend ethnonationalist and religious references side by side to convey the message that the youth is supposed to constitute the united people and become the pioneers of the future by relying on faith and morals. Several historical figures from the official nationalist historiography, and also the deified symbols of the 15 July 2016 coup attempt provide the role models. The choice

\footnotetext{
${ }^{106}$ Çınar, 'Turkey's "Western" or "Muslim" Identity and the AKP's Civilizational Discourse,' 181.

${ }^{107}$ Ensar, 'Ensar Bülteni,' 2017.

${ }^{108}$ TÜGVA, President Erdoğan's Speech at TÜGVA's 5th Youth Reunion, 2019, https://www.youtube.com/watch?v= dtK4w3Y7Ak8.
} 
of dates in his speeches is not a coincidence, but symbolically embraces the crucial anniversaries of official history. This discourse emphasizes the centrality of faith and morals in youngsters' identity as a panacea against 'the criminal gangs and terrorists' which is an evident reference to the PKK, the Gülenists that parted ways with the AKP, and all dissident and leftist youth movements. The overarching message here is that the youth, guided by the AKP following the example of the historical heroes, would be loyal to the faith and morals of the nation, embrace the historical conquest mentality to ward off 'the threats'. Contrary to the previous attempts at widening the people by incorporating groups at the margins, this depiction constructs the people as deserving subjects as loyal and pious attendants of religious, national and authentic values.

The '15 youth' has become a rhetorical artefact for the government and prepared the ground for a new youth policy that initiated a major break from the Kemalist republican culture. Instead of cultivating the youth as the guardians of the secular regime, the AKP vowed to raise 'religious generations'. ${ }^{109}$ As a result, the government altered the education system several times to expand the religious classes and schools, updated the curricula and school books to offer a more nationalist official history narrative.$^{110}$ Outside the formal education, it has also promoted government-oriented youth organizations to ensure that youngsters are indoctrinated and socialized, in line with the ethnoreligious identity.$^{111}$

In the novel version of the populist construction of the people as nation, the dissentful youth is labelled as 'looters' or 'terrorists', and they are excluded from 'the people'. Detention and imprisonment of youth particularly engaged in left-wing or Kurdish activism have become a common practice. After the coup attempt, 70,000 students were imprisoned mostly based on their dissident political or civic activities. ${ }^{112}$ In March 2018, a group of students protesting the military operation in northern Syria, Afrin was arrested by the police. On this occasion, Erdoğan called the students 'traitors to their country' and 'terrorist youth' and demanded that they should be all expelled from the university. Students were put under pretrial detention on charges of spreading propaganda for a terrorist organization, and two male university students claimed that they were tortured in police custody. More recently, in January 2021, students at Boğaziçi University started protests against the top-down appointment of a rector. One of the most active student groups among the protesters was the LGBT union. Government representatives targeted LGBT students as 'perverted' and not fitting in the morals of the nation to delegitimize the protestors and create a negative public opinion. Upon the arrest of several students, Erdoğan stated that 'We will carry our young people to the future, not as the LGBT youth, but as the youth that existed in our nation's glorious past. You are not

\footnotetext{
${ }^{109}$ Demet Lüküslü, 'Creating a Pious Generation: Youth and Education Policies of the AKP in Turkey,' Southeast European and Black Sea Studies 16, no. 4 (2016): 637-49, https://doi.org/10.1080/14683857.2016.1243332; Bilge Yabanci, 'Work for the Nation, Obey the State, Praise the Ummah: Turkey's Government-Oriented Youth Organizations in Cultivating a New Nation,' Ethnopolitics online preprint (2019): 1-33, https://doi.org/10.1080/17449057.2019.1676536; Ayça Alemdaroğlu, 'The AKP's Problem with Youth,' MERIP, 15 December 2018, https://merip.org/2018/12/the-akpsproblem-with-youth/.

${ }^{110}$ Elif Gençkal Eroler, Raising Pious Generations (Istanbul: Iletisim, 2019); K. Inal and G. Akkaymak, Neoliberal Transformation of Education in Turkey: Political and Ideological Analysis of Educational Reforms in the Age of the AKP (Springer, 2012).

${ }^{111}$ Yabanci, 'Work for the Nation, Obey the State, Praise the Ummah.'

${ }^{112}$ Cumhuriyet. 2017. '70 bin öğrenci hapiste.' 2017. https://www.cumhuriyet.com.tr/haber/70-bin-ogrenci-hapiste $-856384$.
} 
the LGBT youth, not the youth who commit acts of vandalism.'113 Drawing discursive borders between ideal youth which constitute the nation and its 'glorious history' and the 'LGBT youth' that are considered against the religion and nation has become an integral part of the power struggle for the AKP.

\section{Sacralized, mothers and chaste women versus feminists}

Women have also been placed at the centre of constructing 'the people as nation' particularly as the political discourse around women increasingly incorporated Islamic and moral references to chastity and sacredness of 'our women'. ${ }^{114}$ The party programme of the AKP is clear about the role of women: 'the AKP prioritises women's issues not because they constitute half of the population but because they are primarily responsible for raising healthy individuals and generations'. ${ }^{115}$ The AKP also targets women's bodies, public and private roles and sexualities, as Erdoğan stated:

As long as the family exists, the nation and the state will perpetuate. As long as the family is cherished, healthy generations will spring. If we are to become a mighty nation, we need mighty families. We need a young and dynamic population. In this sense, the most ennobling position for a woman is motherhood. This is why we say 'strong families with at least three children'. ${ }^{116}$

These statements reveal that women's incorporation into 'the people' is conditioned on their subservience to the gendered nation. Women can become a part of 'the nation' through their contribution to the heteropatriarchal family as mothers undertaking the central roles in raising the 15 July youth. Empowered by this discourse, women and sexual minorities that do not fit in the sacred motherhood are expelled from the authentic nation. Feminists, women belonging to minority sexual orientations, and nonheteropatriarchal practices ${ }_{-}$such as cohabitation and single motherhood $_{\mathcal{A}_{-}}$are considered outside the authentic lifestyle and declared not only alien and immoral but also as an attack against the nation. In 2014, accusing feminists of not understanding the special status that Islam attributes to mothers, Erdoğan stated that

Our religion granted women a position: motherhood. Islam laid heaven under mothers' feet. However, you cannot express this to the feminists who deny motherhood. Those who understand [the importance of motherhood in Islam] are sufficient for us; we move on with them.$^{117}$

Government officials, pro-AKP journalists and theologians have condemned abortion, birth control, C-sections and gay pride in conspiratorial frames as 'plans to wipe out the nation' and 'against the morality of the overwhelming majority of the Muslim nation'. Islamic references are used to substantiate the government's intervention in women's bodies to save the nation.

\footnotetext{
${ }^{113}$ BBC News. 2021. 'Turkey's Erdoğan Denounces LGBT Youth as Police Arrest Students,' https://www.bbc.com/news/ world-europe-55901951.

${ }^{114}$ Ayşe Güneş-Ayata and Gökten Doğangün, 'Gender Politics of the AKP: Restoration of a Religio-Conservative Gender Climate,' Journal of Balkan and Near Eastern Studies 19, no. 6 (2017): 610-27, https://doi.org/10.1080/19448953.2017. 1328887; Dilek Cindoglu and Didem Unal, 'Gender and Sexuality in the Authoritarian Discursive Strategies of "New Turkey,"' European Journal of Women's Studies 24, no. 1 (2017): 39-54, https://doi.org/10.1177/1350506816679003.

${ }^{115}$ AKP, 'Party Programme,' n.d., https://www.akparti.org.tr/parti/parti-programi/.

${ }^{116}$ Milliyet, 'Erdoğan neden 3 çocuk istediğini açıkladı? [Erdoğan explained the reason behind 3 children desire]' 2013, http://www.milliyet.com.tr/siyaset/Erdoğan-neden-3-cocuk-istedigini-acikladi-1650260.

${ }^{117}$ Agence France-Presse, "'Women Not Equal to Men,"' The Guardian, 24 November 2014, https://www.theguardian.com/ world/2014/nov/24/turkeys-president-recep-tayyip-Erdoğan-women-not-equal-men.
} 
Gender equality is rejected for being 'against nature' and women without children were declared 'incomplete and deficient' by Erdoğan. Working women, compared to stay-home moms, were described as mischievous and blamed for neglecting children and family. ${ }^{118}$ The state-controlled religious authority, Diyanet, asserted that 'feminism bears negative connotations for morality and society and equals to indecency' ${ }^{119}$

Not only do women's private choices are used to categorize women as chaste, hence a part of the people, or immoral and not an integral part of the people. The government also attributes political dissidence gendered unchastity and immorality to declare dissident women not a part of 'the people as nation'. To give an example, following her arrest during a protest, Erdoğan shamed Dilşat Aktaş at a public rally by referring to her as 'that woman or girl, of course, I cannot be sure'. ${ }^{120}$ Because Aktaş is an activist woman who joined street protests against the government, Erdoğan made an inference about her virginity and implied that she is likely to engage in extra-marital sex-forbidden in Islam- and therefore an 'immoral woman'. Although such statements do not have direct Islamic references, they include a moral judgement derived from religious principles. Being a vociferous political dissident means exclusion from the idealized category of 'sacred mothers' and hence a from the people.

Hegemonic discourse regulates policy choices and justifies the violation of the rights of citizens who are considered outside 'the people'. For instance, the Ministry of Family and Social Policies' does not consider unmarried or divorced single women eligible for social assistance. Women who have the right to receive these benefits are put under constant surveillance to ensure they have 'a morally acceptable lifestyle and relations'. ${ }^{121}$ Similarly, reproductive and sexual health services in public health clinics are offered to married women, while trans and single women are regularly denied access. ${ }^{122}$ To sum, the essence of the political discourse surrounding women is similar to the youth discourse. It draws strict boundaries of the people by defining the ideal women informed by religious practice and service to the nation mothers and caretakers.

\section{'People as the ummah': pan-Ottomanism and the transnationalizaion of populism}

Whilst 'the people and the elites' antagonism has to be continuously reconstructed, the categories of 'the people' and 'the elites/enemies' are not limited to citizenship and borders. Particularly following the Arab Spring and the Syrian civil war, the AKP stretched its discursive references to the people to incorporate a broad audience beyond Turkey's borders. In doing so, the AKP considerably capitalized on a novel interpretation of panOttomanism which is realized through a mixture of direct references to the Ottoman society where diverse groups lived together (allegedly in peace and harmony) in direct contrast to 'the Western civilization' depicted as non-trustable, dishonest and cynical. ${ }^{123}$

\footnotetext{
${ }^{118}$ Rose Troup, 'Turkey's President Reckons Women Are "Deficient" Unless They Have Children,' BuzzFeed News, 2016, https://www.buzzfeednews.com/article/rosebuchanan/women-without-children-are-incomplete-says-turkish-leader.

${ }^{119}$ Hürriyet, 'Diyanet, feministleri kızdırdı [Diyanet angered feminists]' 2008, http://www.hurriyet.com.tr/gundem/diyanetfeministleri-kizdirdi-8434696.

${ }^{120}$ Kazete, 'Erdoğan'ın "kadın mıdır, kız mıdır" dediği Dilşat Aktaş gözaltında [Dilsat Aktas is under arrest]' 2011, https:// kazete.com.tr/haber/Erdoğanin-kadin-midir-kiz-midir-dedigi-dilsat-aktas-gozaltinda-55868.

${ }^{121}$ Güneş-Ayata and Doğangün, 'Gender Politics of the AKP.'

${ }^{122}$ Feride Acar and Gülbanu Altunok, 'The "Politics of Intimate" at the Intersection of Neo-Liberalism and NeoConservatism in Contemporary Turkey,' Women's Studies International Forum, Gendering Social Policy and Welfare State in Turkey, 41 (2013): 14-23, https://doi.org/10.1016/j.wsif.2012.10.001.

${ }^{123}$ Tokdogan, Nagehan. 2018. Neo-Ottomanism. Istanbul: Iletisim.
} 
Pax-Ottomania has become a significant reference to contrast Turkish and European contexts. Ethnic and religious strife and communal conflicts in the Balkans, Middle East and Caucasia are always mentioned with reference to the peaceful co-existence of communities under the Ottoman rule which European colonialism destroyed. The AKP compares the Ottoman era to the current far-right and Islamophobic discourse to entrench its claim 'the people as the ummah'. Especially, the anti-immigration policies and far-right public opinion in Europe are underlined as a sign of the democratic shortcomings and double standards of the West. Contrarily, Turkey is praised for its moral superiority, welcoming more than 4 million refugees:

The Neo-Nazi virus will spread over and encircle us, and the Western governments won't disrupt their comfort if we do not oppose strongly. We will continue to speak of the bitter truth. Otherwise, the Western media would exacerbate the anti-Islam feelings. Neo-Nazi organizations should be treated like ISIS, al-Shabab or PKK. Islamophobia should be fought with the same determination we have seen in the fight against anti-Semitism in the aftermath of the Holocaust. ${ }^{124}$

The AKP also re-constructs the history as an incessant struggle between the two fundamentally irreconcilable 'Western' (read Christian) civilization and Islamic civilization. Unsurprisingly, 'civilizations' are conceived as monolithic and static worldviews that shape and reflect the mindset of the people and politicians. ${ }^{125}$ The ex-Prime Minister Davutoğlu's vision of world politics is an excellent example of the AKP's discourse in evoking an essentially anti-Western construction of 'the people as ummah'. ${ }^{126}$ Davutoğlu claimed that the West promotes pluralism 'only if it serves [its own] monopoly of supreme civilization which aims to destroy and peripheralize the authentic cultures and civilizations. ${ }^{\prime 27}$ The statement reflects a widely held conviction among the nationalistconservative circles that the European support for human rights and pluralism masks the intention to delay Turkey's development. In fact, not so rarely, government officials assert

Q10 that 'our civilisation' offers better norms of equality, justice and development. In the words of Erdoğan: 'we do not need to look elsewhere, contemporary universal values and principles were strongly defended and practised by the Ottoman and Seljuk states'.128 This construction of a transnational 'people' reflects a defensive attitude vis-à-vis the West embedded in historical scepticism towards the West as well as the nationalist belief in Turkey's leading role among Muslim societies.

Based on this essentialist reading of history that whitewashes one's own history and highlight the crimes of the others, the AKP's builds a claim to restore not only the dignity and confidence of Turkey but also to end 'the long-suffering of Muslims'. ${ }^{129}$ According to the AKP, Turkey's foreign policy goals have to represent ethnic, kin, linguistic and Islamic communities worldwide. This perception imagines 'the people' beyond the citizenship and borders as the Islamic ummah and nominates Turkey as the authentic voice of

\footnotetext{
${ }^{124}$ Presidency Office, 'Ümmetin Bekasını Ilgilendiren Hususlarda Tek Yürek, Tek Bilek Olup Beraberce Hareket Etmeliyiz,' 2019, https://www.tccb.gov.tr/haberler/410/102635/-ummetin-bekasini-ilgilendiren-hususlarda-tek-yurek-tek-bilekolup-beraberce-hareket-etmeliyiz-.

${ }^{125}$ Ahmet Davutoğlu, Medeniyetlerin Ben-Idraki Medeniyet Teorisine Mukaddime [Self-Perception of Civilizations] (Istanbul: Küre, 2018); Ibrahim Kalin, 'Worldview, Existence and Order' Divan: Disiplinlerarası Çalışmalar Dergisi, 29 (2010): 1-61.

${ }^{126}$ Bill Park, "Turkey's 'New' Foreign Policy?' Mediterranean Politics 19: 2 (2014): 161-64.

${ }^{127}$ Cited in Çınar, 'Turkey's "Western" or "Muslim" Identity and the AKP's Civilizational Discourse,' 184.

${ }^{128}$ Çınar, 190.

${ }^{129}$ Ümmit Cizre, 'Leadership Gone Awry,' Middle East Report 276, no. Fall (2015): 36-43.
} 
Muslims and underdeveloped nations. Erdoğan's statement following the 2019 mosque shooting in New Zealand shows how the AKP positions Turkey as the voice of a global community of 'the downtrodden people':

I call out to those crusader remnants who attack us. You won't silence us. You cannot prevent the sacred march of the Turkish nation. Turkey means hope in the world today. We won't kneel in front of anti-Muslims. Even if you don't wish to see it, we will continue to defend Jerusalem and Gaza. We don't want a new war between the cross and the crescent. But, if you are so willing, we will do what is necessary.

The self-attributed leadership role ('Turkey means hope in the world today') emanates from an essentially nationalist perspective ('Turkey as the leading Muslim nation'). Very much in line with the historical tradition, the AKP leadership also believes that the rebirth of powerful Turkey would mean the revival of the entire Islamic civilization. 'The Islamic world' has become a part of the AKP's political discourse when highlighting the selfassigned 'historic mission' of Turkey. ${ }^{130}$ The imagination of 'the people as ummah', is built on an inherent ethnonational superiority over the rest of the Muslim world, as exemplified by Erdoğan's statement on the vast symbolic borders of Turkey: 'Izmir's borders span from Vienna to the shores of the Adriatic Sea, from East Turkistan [China's autonomous region of Xinjiang] to the Black Sea'. ${ }^{131}$

The AKP's discourse has been successful to no small extent to make its claim for leadership of 'the oppressed ummah' by appealing to anti-colonial and Third Worldist ideas particularly in underdeveloped countries. This discourse echoes current insecurities and anxieties of immigrant groups ${ }_{\lambda}$ Turkish or otherwise ${ }_{\lambda}$ settled in the West. The AKP has built international alliances through friendly intellectuals, academics and think-tanks to boost Turkey's image as the leader of 'a new Third Worldist camp' against the Western hegemony. ${ }^{132}$ Moreover, Turkish state agencies established a sphere of influence in regions with Turkish-Muslim and Muslim immigrants and minorities ${ }^{133}$ and even shapes the private lives of individuals in Europe by creating subjectivities loyal to the Turkish version of Islam. ${ }^{134}$ The discursive construction of 'the people' as a global entity entrenches and reifies self-assigned role as representative of 'the ummah'. The AKP's populism has become a transnational claim built on pan-Ottomanism and ethno-centric nationalism, a belief that religious and national identity are inseparable.

\footnotetext{
${ }^{130}$ Cenk Saraçoğlu and Özhan Demirkol, 'Nationalism and Foreign Policy Discourse in Turkey Under the AKP Rule: Geography, History and National Identity,' British Journal of Middle Eastern Studies 42, no. 3 (2015): 301-19, https:// doi.org/10.1080/13530194.2014.947152.

${ }^{131}$ Islamism Map, 'Erdoğan's Izmir Sppech,' Twitter, 2019, https://twitter.com/islamismmap/status/ 1085850691376242688.

${ }^{132}$ Sinem Adar and Halil Ibrahim Yenigun, 'A Muslim Counter-Hegemony?' Jadaliyya, 2019, https://www.jadaliyya.com/ Author/8134.

${ }^{133}$ Zana Çitak, "Between "Turkish Islam" and "French Islam": The Role of the Diyanet in the Conseil Français Du Culte Musulman,' Journal of Ethnic and Migration Studies 36, no. 4 (2010): 619-34, https://doi.org/10.1080/ 13691830903421797; Erdi Öztürk and Semiha Sözeri, 'Diyanet as a Turkish Foreign Policy Tool: Evidence from the Netherlands and Bulgaria,' Politics and Religion 11, no. 3 (2018): 624-48, https://doi.org/10.1017/S175504831700075X.

${ }^{134}$ Chiara Maritato, 'Addressing the Blurred Edges of Turkey's Diaspora and Religious Policy: Diyanet Women Preachers Sent to Europe,' European Journal of Turkish Studies. Social Sciences on Contemporary Turkey, no. 27 (2018), http:// journals.openedition.org/ejts/6020; Kerem Öktem, 'New Islamic Actors after the Wahhabi Intermezzo: Turkey's Return to the Muslim Balkans,' Working Paper (European Studies Centre, University of Oxford, 2010).
} 


\section{Conclusion}

The salience of nationalism and religion in populist discourse has been subject to various analyses isolated from each other. Scholars have debated the role of religion in the discourse and appeal of populists by mostly referring to the instrumentalization of religion'. The role of nationalism has been analysed without acknowledging the role of religion in determining who belongs to the nation in numerous contexts. These explanations ignore the co-constituent role of religion and nationalism in populism's hegemonic production of 'the people versus the elites' antagonism. This study has argued that the intellectual and historical factors of nation-building fused religion and nationalism inseparably in several contexts and should be duly included in the analyses of contemporary populism.

The chief contribution of this study is to provide an in-depth analysis of the multidimensional relationship between religion, nationalism and populism through the case of Turkey and the AKP's populism. The empirical analysis has shown that populism relies on the historical co-development of religion and nationalism to draw and re-draw the borders of 'the people'. Discourse analysis has revealed how a particular version of nationbuilding based on ethnodoxy can be promoted as part of the populist bid for hegemonic power and determine the inclusion and exclusion by associating the people with a select part of the population. This way, populists normalize and legitimize the exclusion and discrimination of some groups and individuals.

The study outlined crucial shifts in populism's rapport with religion and nationalism over time and identified three parallel constructions of the people and elites antagonism in Turkey. Initially, the AKP has referred to Islam as an overarching belonging in line with the pan-Islamist tradition to construct 'people as underdogs' against secular elites. The Islamic common culture was presented as a strong cement to bring together Muslim masses and ethnic or sectarian minorities in their opposition against the secular elites. However, Islam was a unifying force to mask and assimilate diversity. Eventually, the AKP failed to maintain support for 'people as underdogs' as its growing undemocratic turn was challenged in the post-2013 period. As the AKP's authoritarian practices deepened, it has re-articulated a more exclusionary form of populism. New imagery of 'the people as nation' was built on nationalist-conservative tradition. Women and youth policies illustrated the construction of people as nation against the enemies within. The AKP turned to the youth as the prototype of the ideal people to cultivate a new with Islamic and nationalist ideals. Similarly, the control over women's bodies and social roles through Islamic-nationalist references has become a key reference in the AKP's power struggle to build 'people as nation'. Finally, populism has also found a transnational breeding ground through a fusion between religion and nationalism. 'The people as ummah' has come to denominate the ethnic kin and linguistic communities, underdeveloped regions, immigrants and refugees against the 'xenophobic and hypocritical West'. However, the transnational reverberations of populist discourse are anchored onto the leading role of Turkey and remain an essentially nationalist imagination.

While the analysis provided in this study is not exhaustive, the AKP's populism is representative of a broader phenomenon. The way that populism, nationalism and religion relationship shapes in a particular context depends on not only the contemporary populists' political needs and instrumentalization of religion and nationalism for political 
ends. The role of religion and nationalism in populism should also be approached through the prism of the historical co-constitution of religious identity and nationalism. The dominant public discourse that populists circulate about the different versions of 'the people' is an integral part of the power struggle. These versions of constructing 'the people' also plays a transformative role in the thinking and understanding of the wider public about who belongs to the people. The case of Turkey and the AKP is a testament that the inherited rapport of nationalism and religion can allow populists to echo the learned anxieties, moral evaluations and cultural pretexts when amplifying socio-political contradictions and to reach out to broad audiences. In this sense, the study is a call for a more circular theorization between religion, nationalism and contemporary populist discourse.

\section{Disclosure statement}

Q11 No potential conflict of interest was reported by the author(s).

\section{Funding}

This study received funding from the European Union's Horizon 2020 research an innovation programme under the Marie Skłodowska-Curie Project 'CRAFT' with Grant agreement ID 795117;

Q2 Marie Sklodowska-Curie [795117];

Q3

\section{ORCID}

Bilge Yabanci (D) http://orcid.org/0000-0002-3937-9789 